\title{
POLITIK HUKUM PERUNDANG-UNDANGAN TERHADAP ANAK LUAR NIKAH
}

\author{
Muammar ${ }^{1}$
}

Email: ammarrachman682@gmail.com

\begin{abstract}
The formation of the 1974 Marriage Law is based on Islamic Law, which became a problem when the Constitutional Court gave a decision on the judicial review of the Marriage Law with a decision that was considered by the public that the decision was against Islamic law. The research problem in this article is, How is the Politics of Law in the Reform of Legislation in the Post-Constitutional Court Ruling on Marriage related to the status of children outside of marriage? Does the Constitutional Court Decision No 46 / PUU-VII / 2010 contradict Islamic law? The research approach used in this research is normative juridical. The results of the study indicate that children who are born must receive legal protection. If this is not the case, then the children who are born outside of marriage will suffer losses. The relationship between the child and the father does not only occur because of a legal marriage, but can also be based on evidence of a blood relationship between the child and the boy as the father. This is because birth is a legal result of a legal relationship in which there are reciprocal rights and obligations between the child, mother and father. This decision refers, because there is a relationship that is carried out without any legal conditions for marriage, both religiously and in a state, so that it does not cause harm which implies a child who has not done anything wrong. In conclusion, the Constitutional Court granted the renewal of the norm in article 43 of the Marriage Law No. 1 of 1974, which is to provide constitutional rights for children born out of wedlock whether born from a legally valid marriage or not. The decision of the Constitutional Court related to the addition of article 43 paragraph (1) of this marriage law is still in the spirit of Islam as the struggle of Muslims to be able to apply their religious values in this law is not only legally religiously or nationally.
\end{abstract}

Keywords: Constitutional Court, Out of wedlock children, Political Law Legislation.

\begin{abstract}
Abstrak
Pembentukan Undang-Undang (UU) Perkawinan Tahun 1974 berdasarkan Hukum Islam, menjadi permasalahan saat Mahkamah Konstitusi (MK) memutuskan judicial review atas UU perkawinan, bagi masyarakat bertentangan dengan hukum Islam. Permasalahan penelitian ini, Bagaimana Politik Hukum dalam Pembaharuan Peraturan Perundang-Undangan dalam UU Perkawinan Pasca Putusan MK terkait dengan status anak diluar nikah? Apakah Putusan MK No 46/PUU-VII/2010 bertentangan dengan hukum Islam? Pendekatan penelitian ini yuridis normatif. Hasil penelitian menguraikan, anak yang lahir harus mendapat perlindungan hukum. Jika tidak, yang dirugikan adalah anak yang dilahirkan diluar perkawinan. hubungan anak dengan bapak tidak semata-mata terjadi karena adanya sebuah perkawinan yang sah, tapi berdasar pembuktian adanya hubungan darah antara anak dan laki-laki sebagai bapak. Hal ini karena kelahiran adalah akibat hukum dari hubungan hukum yang terdapat hak
\end{abstract}

\footnotetext{
${ }^{1}$ Institut Agama Islam Negeri Sutan Amai Gorontalo
} 
dan kewajiban secara timbal balik. Putusan ini mengacu, sebab adanya hubungan yang dilakukan tanpa adanya syarat pernikahan yang sah, baik secara agamadan negara, sehingga tidak menimbulkan kerugian yang berimplikasi pada anak yang tidak melakukan kesalahan. Pembaharuan norma dalam pasal 43 UU Perkawinan No. 1 Tahun 1974, memberikan hak konstitusional anak yang dilahirkan di luar nikah baik yang lahir dari pernikahan yang sah secara agama atau tidak. Putusan MK terkait penambahan pasal 43 ayat (1) UU perkawinan masih bernafaskan Islam sesuai perjuangan ummat Islam untuk dapat menjalankan nilai-nilai agamanya dalam UU ini hannya tidak sah secara agama dan Negara.

Kata Kunci : Mahkamah Konstitusi, Anak Luar Nikah, Politik Hukum Perundangundangan.

\section{A. PENDAHULUAN}

Undang-undang Dasar 1945 memberikan jaminan terhadap kemerdekaan penduduknya untuk memeluk agamanya masing-masing dan beribadah menurut agama dan kepercayaannya. ${ }^{2}$ Sebagaimana tercantum dalam Konstitusi Negara. Meski memberikan jaminan kemerdekaan terhadap pemelukan agama, akan tetapi pada kenyataanya negara juga memberikan batasan terhadap beberapa agama saja yang diakui oleh negara, agama tersebut yaitu Islam, Kristen, Katholik, Hindu, Bunda dan Konghucu. $^{3}$

Badan Pusat Statistik sensus penduduk pada tahun 2010 mencatatkan bahwa mayoritas penduduk Indonesia adalah pemeluk agama islam dengan persentasi 87,2 persen dari keselurahan penduduk Indonesia dan diikuti pemeluk agama Kristen, kemudian katholik dan selanjutnya berurutan agama Hindu, Bunda dan Konghucu. ${ }^{4}$ Keberadaan mayoritas muslim di Indonesia ini tidak lantas menjadikan negara Indonesia ini mendasarkan konstitusinya pada penerapan syari'ah islam atau menjadikan Indonesia sebagai negara islam, akan tetapi kita tidak dapat memungkiri bahwa hukum islam mendapatkan tempat dalam kodifikasi hukum di Indonesia.

Indonesia telah melegislasi beberapa undang-undang yang menfasilitasi pelaksanaan ajaran islam di Indonesia dengan menerbitkan undang-undang No.1/1974 tentang Perkawinan yang kemudian disusul dengan PP No.9/1975. Selanjutnya ditetapkan pula ketentuan tentang Wakaf dalam PP No.28/1977. Pada tahun 90an,

\footnotetext{
${ }^{2}$ Pasal 29 UUD 1945 oktober 2013

3 http://www.indonesia-investments.com/id/budaya/agama/item69 di akses pada tanggal 6 ${ }^{4}$ Ibid.
} 
setelah terbentuknya Ikatan Cendekiawan Muslim Indonesia pada 8 desember 1990, Indonesia kembali melakukan legislasi dalam bidang hukum islam dengan diterbikannya UU No.7/1989 tentang Peradilan Agama, sekaligus menempatkan Peradilan Agama sebagai lembaga peradilan negara yang diatur dalam UU No.14/1970 tentang Pokok Pokok Kekuasaan Kehakiman, disusul dengan UU No.10/1998 tentang Perbankan (pengganti UU No.7/1992), UU No.38/ 1999 tentang Zakat, dan Inpres No.1/1991.tentang Penyebarluasan Kompilasi Hukum Islam. ${ }^{5}$

Semua peraturan yang telah disebutkan diatas tentunya memiliki tujuan atau harapan dari terbentuknya masing-masing peraturan yang pada dasarnya adalah pemberlakuan syariat islam di Indonesia dengan melalui jalur formal yaitu melalui diterbitkannya undang-undang oleh negara. Dari semua peraturan diatas, penulis hanya ingin menggali lebih jauh politik perundang-undangan yang terdapat dalam undangundang no 1 tahun 1974 tentang perkawinan, khususnya terkait dengan masa pasca putusan mahkamah konstitusi.

Pembentukan UU Perkawinan sempat menuai tarik ulur dan menimbulkan kontroversi yang sangat besar pada seluruh kalangan agama islam yang saat itu menolak RUU Perkawinan pada tahun 1973 yang dianggap bertentangan dengan ajaran agama islam bahkan pembentukannya juga tidak melibatkan dari Departement agama. Hal ini mengakibatkan terjadinya demonstrasi yang menyebabkan umat islam menduduki gedung DPR dan mengakibatkan sidang berujung tanpa hasil, akan tetapi setelah KH Bisri Syansuri dan KH Masykur bertemu dengan presiden soeharto kemudian tercapailah dua kesepakatan. Pertama, Hukum islam dalam hukum perkawinan tidak akan dikurangi atau dirubah. Kedua, UU no 22 tahun 1946 dan UU no 14 tahun 1970 dijamin kelangsungannya. Ketiga, hal-hal yang tidak sesuai agama islam dalam RUU dihapuskan. Keempat, Pasal 2 RUU dirumuskan sebagai berikut: ayat (1) Perkawinan sah apabila dilakukan menurut hukum masing-masing agamanya dan kepercayaanya itu; (2) tiap-tiap perkawinan wajib dicatat demi ketertiban administrasi negara, dan yang terakhir mengenai perceraian dan poligami perlu

5 Dadan Muttaqien, Legislasi Hukum Islam di Indonesia Dalam Prespektif Politik Hukum, http://master.islamic.uii.ac.id/index.php/Artikel/Legislasi-Hukum-Islam-di-Indonesia-dalam-PrespektifPolitik-Hukum.html di akses pada tanggal 6 oktober 2013. 
diusahakan adanya ketentuan-ketentuan guna mencegah terjadinya kesewenangwenangan. ${ }^{6}$

Uraian diatas menjelaskan bahwa pembentukan UU perkawinan tahun 1974 didasarkan pada hukum Islam, Hal ini kemudian menjadi sebuah permasalahan ketika mahkamah konstitusi memberikan putusan atas judicial review dalam UU perkawinan dengan putusan yang dinilai oleh masyarakat bahwa putusan tersebut bertentangan dengan hukum Islam. Hakim agung Habibburahman menyatakan bahwa Amar putusan MK yang berisi pengakuan terhadap anak di luar nikah bertentangan dengan maqashid asy syari'ah dan amat menusuk perasaan umat Islam yang menjunjung tinggi ajaran Islam. ${ }^{7}$ Untuk itu, penulis ingin mengkaji politik pembaharuan peraturan perundangundangan yang melandasi putusan Mahkamah Konstitusi berkaitan dengan status anak diluar nikah yang memiliki hubungan keperdataan dengan ayahnya yang dianggap bertentangan dengan hukum islam

Penelitian ini terkait dengan jenis penelitian hukum normatif yang dilakukan dengan pendekatan secara yuridis normatif yaitu penelitian hukum yang dilakukan dengan cara meneliti bahan pustaka, yang menggunakan obyek kajian penulisan berupa pustaka-pustaka yang ada, baik berupa buku-buku, majalah, dan peraturan yang mempunyai korelasi terhadap pembahasan masalah.

Adapun rumusan permasalahan yang ingin dikaji, yakni: l. Bagaimana Politik Hukum dalam pembaharuan peraturan perundang-undangan dalam Undang Undang perkawinan pasca Putusan Mahkamah Konstitusi terkait dengan status anak diluar nikah? dan 2. Apakah Putusan Mahkamah Konstitusi No 46/PUU-VII/2010 bertentangan dengan hukum Islam?

\section{B. PENGERTIAN POLITIK HUKUM PERUNDANG-UNDANGAN}

Berbicara terkait dengan politik perundang-undangan, kita perlu mengetahui terlebih dahulu makna dari politik hukum. Hal ini dikarenakan politik perundangundangan merupakan sub system dari politik hukum. Banyak sekali Para pakar hukum yang telah mendefinisikan politik hukum, antara lain Mahfud MD yang menyatakan

\footnotetext{
${ }^{6}$ Wawan Hermawan, Pengaruh Konfigurasi Politik terhadap Hukum Perkawinan di Indonesia, http://file.upi.edu/Direktori/FPIPS/M K D U/19740209200501lWAWAN HERMAWAN/Pengaruh Ko nfig Politik trhdp Huk Perk-Jurnal FPIPS.pdf diakses pada tanggal 6 oktober 2013.

${ }^{7}$ http://news.detik.com/read/2013/06/04/110906/2264095/10/hakim-agung-putusan-mk-soalanak-biologis-menusuk-perasaan-umat-islam
} 
bahwa politik hukum merupakan "legal policy", atau garis (kebijakan) resmi tentang hukum yang akan diberlakukan baik dengan pembuatan hukum baru maupun dengan pergantian hukum lama, dalam rangka mencapai tujuan Negara. Definisi ini secara substantif sama dengan definisi yang dikemukakan oleh Padmo Wahjono yang menyatakan bahwa politik hukum adalah kebijakan dasar yang menentukan arah, bentuk, maupun isi hukum yang akan dibentuk. ${ }^{8}$

Politik hukum ini maknanya sangat luas sekali yang kemudian dipersempit wilayahnya menjadi Politik Perundang-undangan, yang didefinisikan dengan arah kebijakan pembentukan peraturan perundang-undangan. Jadi tidak termasuk di sini yaitu; kebijaksanaan mengenai "penerapan" dan "penegakannya", sementara sasaran dari politik perundang-undangan adalah pembaharuan dan pembentukan peraturan perundang-undangan, dan penginventarisasian dan penyesuaian hukum yang berlaku ${ }^{9}$

Dari pengertian diatas, maka setiap bentuk Undang-Undang yang muncul dan pembaharuannya merupakan ranah dari Politik Perundang-undangan, begitu pula dengan penyesuaian hukum yang terjadi dalam tatanan hukum Indonesia, oleh karena itu, penulis mengambil sikap bahwa tulisan ini merupakan bagian dari politik perundang-undangan.

UU perkawinan 1974 merupakan sebuah perwujudan dari hasil pembentukan hukum pemerintahan era orde baru yang mengambil dasar dari hukum islam secara keseluruhan demi memecahkan permasalahan yang terjadi dalam bidang perkawinan. Hingga saat ini UU tersebut belum mengalami perubahan, baik secara parsial maupun keseluruhan, yang berarti bahwa UU tersebut dinilai tidak bertentangan dengan citacita bangsa dan tujuan negara, setidaknya sebelum putusan mahkamah konstitusi No 46/PUU-VII/2010 diterbitkan.

\section{LATAR BELAKANG MUNCULNYA PUTUSAN MAHKAMAH KONSTITUSI NO 46/PUU-VII/2010.}

Salah satu kewenangan yang diberikan oleh UUD terhadap Mahkamah Konstitusi ialah melakukan pengujian atas Undang-undang terhadap UUD pada

\footnotetext{
${ }^{8}$ Moh. Mahfud MD, Politik Hukum di Indonesia,Edisi revisi, Rajawali Press, Jakarta, 2009. Hlm: 1

${ }^{9}$ Jazim Hamidi, Bahan kuliah magister hukum Universitas Islam Indonesia.
} 
tingkat pertama dan terakhir yang putusanya bersifat final. ${ }^{10}$ Kewenangan ini menjadikan Mahkamah Konstitusi sebagai rujukan dari kajian politik peraturan perundangan-undangan selain dari lembaga legislatif yang memiliki kewenangan pembentukan. Namun, pengujian atas UU terhadap UUD atau yang biasa disebut dengan judicial review ini hanya diperuntukkan bagi warga negara indonesia yang hak konstitutionalnya terlanggar oleh adanya UU tersebut.

Munculnya putusan Mahkamah Konstitusi No 46/PUU-VII/2010 diawali dari permohonan uji materiil yang dilakukan oleh Aisyah Mochtar alias Machica binti $\mathrm{H}$ Mochtar Ibrahim yang melakukan pernikahan dengan Moerdiono secara islam dan tidak dilakukan pencatatan ke dalam buku akta nikah atau setidaknya tidak memiliki buku nikah dan melahirkan anak yang bernama Muhammad Iqbal Ramadhan bin Moerdiono yang juga disertakan sebagai pemohon.

Permohonan ini pada dasarnya mempermasalahkan dua pasal dalam UU perkawinan yaitu pasal 2 dan pasal 43, namun penulis disini hanya akan membahas mengenai pasala 43. Pasal 43 ayat (1) yang terdapat dalam UU Perkawinan yang berbunyi bahwa "Anak yang dilahirkan diluar perkawinan hanya mempunyai hubungan perdata dengan dengan ibunya dan keluarga ibunya". Pasal ini dianggap bertentangan dengan UUD 1945 pasal 28B ayat (2) yang menyatakan bahwa "setiap anak berhak atas kelangsungan hidup, tumbuh, dan berkembang serta berhak atas perlindungan dari kekerasan dan diskriminasi".

Pemohon berdalih bahwa hak kostitusional yang telah dilanggar dan dirugikan atas adanya pasal 43 adalah hak yang dijamin dalam pasal 28B ayat (2) karena pernikahan yang dilakukan oleh kedua orang tuanya merupakan sebuah perkawinan yang sah menurut agama dan kepercayaanya, sehingga pasal 43 yang yang kemudian tidak memberikan kepemilikan hubungan perdata dengan ayah atau bapak, dan menimbulkan ketidaksahan dari status hukum yang dimiliki oleh pemohon dalam hal ini Muhammad Iqbal Ramadhan.

Permohonan inilah yang kemudian memunculkan putusan Mahkamah Kosntitusi No 46/PUU-VII/2010 yang kemudian dirasa bertentangan dengan hukum Hlm: 135.

${ }^{10}$ Ni'matul huda, lembaga Negara dalam masa Transisi Demokrasi, UII Press, Yogyakarta, 2007. 
islam dan tidak sesuai dengan tujuan dibentuknya UU No. 1 Tahun 1974 yang didasarkan pada hukum islam.

\section{PERTIMBANGAN HUKUM PUTUSAN MAHKAMAH KONSTITUSI}

Putusan Mahkamah konstitusi memuat dua pendapat hukum yang berasal dari pemerintah, Dewan Perwakilan Rakyat, pertimbangan hukum oleh Mahkamah Konstitusi. Pasal 43 ayat (1) UU perkawinan yang menyatakan bahwa "anak yang dilahirkan diluar perkawinan hanya mempunyai hubungan perdata dengan ibunya dan keluarga ibunya" menurut pemerintah bertujuan untuk memberikan perlindungan dan kepastian hukum terhadap hubungan keperdataan antara anak dan ibunya serta keluarga ibunya, karena suatu perkawinan yang tidak dicatatkan menurut hukum tidak sah, sehingga para pemohon tidak memiliki legal standing yang sah dikarenakan tindakan pernikahan yang dilakukan oleh pemohon melanggar hukum dan tidak sejalan dengan pasal 28J ayat (2) UUD yang menyatakan bahwa "dalam menjalankan hak dan kebebasannya, setiap orang wajib tunduk kepada pembatasan yang ditetapkan dengan undang-undang dengan maksud semata-mat untuk menjamin pengakuan serta penghormatan atas hak dan kebebasan orang lain dan untuk memenuhi tuntutan yang adil sesuai dengan pertimbangan moral, nilai-nilai agama, keamanan, dan ketertiban umum dalam suatu masyarakat yang demokratis".

Pendapat hukum yang hampir sama juga dikemukakan oleh Dewan Perwakilan Rakyat yang menyatakan bahwa pasal 43 ayat (1) akan menjamin terwujudnya tujuan perkawinan, serta memberikan perlindungan dan kepastian hukum terhadap status keperdataan anak dan hubungan ibu serta keluarga ibunya. Apabila pasal 43 ini dibatalkan, maka hal ini akan berimplikasi terhadap status keperdataan anak yang lahir dari perkawinan yang tidak dicatat dan ketentuan pasal ini tidak bertentangan dengan pasal 28B ayat (1) dan ayat (2) serta pasal 28D ayat (1) UUD 1945.

Dua Pendapat diatas berbeda dengan pendapat Mahkamah Konstitusi yang menyatakan bahwa untuk menjawab permasalahan mengenai frasa "yang dilahirkan diluar perkawinan"dalam perspektif luas, perlu dijawab juga terkait dengan sahnya seorang anak, bahwa seorang perempuan tidak mungkin hamil tanpa terjadinya pertemuan antara ovum dan spermatozoa baik melalui hubungan seksual maupun 
melalui cara lain berdasarkan perkembangan teknologi yang menyebabkan terjadinya pembuahan.

Mahkamah Konstitusi menyatakan bahwa tidak tepat dan tidak adil jika hukum membebaskan laki-laki yang menyebabkan terjadinya kehamilan dan kelahiran anak dari tanggung jawabnya sebagai seorang bapak dari anak tersebut, terlebih seiring perkembangan teknologi hal tersebut dapat dibuktikan. Perlindungan terhadap hakhak anak merupakan bentuk pembelaan terhadap hak asasi manusia. ${ }^{l l}$ Oleh karena itu hubungan antara anak dengan bapak tidak semata-mata terjadi karena adanya sebuah perkawinan yang sah, akan tetapi juga dapat didasarkan pada pembuktian adanya hubungan darah antara anak dan laki-laki tersebut sebagai bapak. Hal ini dikarenakan kelahiran merupakan akibat hukum dari sebuah hubungan hukum yang di dalamnya terdapat hak dan kewajiban secara bertimbal balik anatara anak, ibu dan bapak.

Mahkamah Konstitusi juga menambahkan bahwa terlepas dari soal prosedural administratif perkawinannya, anak yang dilahirkan harus mendapatkan perlindungan hukum. Apabila hokum dijadikat "alat" untuk meraih cita-cita, mencapai tujuan bangsa dan Negara maka politik hokum diartikan sebagai arah yang harus ditempuh dalam pembuatan, penegakan hokum atau mereformasi hokum guna mencapai cita-cita dan tujuan bangsa dan Negara. Sebagaimana politik hokum adalah sebagai proses pencapaian cita-cita dan tujuan Negara. ${ }^{12}$ Jika tidak demikian, maka yang akan dirugikan adalah anak yang dilahirkan diluar perkawinan, padahal anak tersebut tidak tidak berdosa karena kelahirannya diluar kehendaknya.

\section{E. PUTUSAN MAHKAMAH KONSTITUSI PRESPEKTIF HUKUM ISLAM}

Putusan Mahkamah Konstitusi terkait dengan "anak diluar perkawinan yang mendapatkan hubungan perdata dengan ayahnya" ini menuai kontroversi di kalangan ummat Islam di Indonesia. Hokum islam dalam konsepsi orang muslim merupakan kategori normative yang harus dipatuhi. ${ }^{13} \mathrm{Hal}$ ini didasarkan pada Hadist Rasulullah yang diriwayatkan oleh Imam Turmudzi yang berbunyi “ apabila seorang laki-laki

\footnotetext{
11 Frans Magnis Suseno, Etika Politik Prinsip-prinsip Moral Dasar Kenegaraan Modern (Jakarta: Gramedia Pustaka Utama, 1999), hlm. 295.

${ }_{12}$ Moh Mahfud MD, "Politik Hukum dalam Perda Berbasis Syariah", Jurnal Hukum "IUS QUIA IUSTIUM”, Vol. 14, No. 1, (Januari 2007),hlm. 8.

13 Syamsul Anwar, Epitemologi Hukum Islam dalam al-Mustasfa min "Ilm al-Usul karya alGazali (450505H/1058-1111 M), Disertasi, tidak diterbitkan (Yogyakarta: Pps. UIN Sunan Kalijaga, 2000), hlm 1.
} 
berzina dengan seorang wanita merdeka atau budak wanita, maka anaknya anak zina yang tidak mewarisi maupun di warisi"14. Penulis kitab Tuhfah al Ahwadzi yang menukil perkataan Ibnul Malak juga menyebutkan bahwa anak (zina) itu tidaklah mewarisi laki-laki yang menzinahi ibunya dan tidak juga mewarisi suadara-saudara kerabatnya karena pewarisan adalah berdasarkan nasab sedangkan anak itu tidaklah memiliki hubungan nasab dengan laki-laki yang berzina tersebut. ${ }^{15}$

Hadist lain yang dijadikan dasar bahwa hukum islam tidak memberikan nasab terhadap anak hasil zina ialah hadist yang diriwayatkan oleh amr bin Syuaib ra, dari ayahnya, dari kakeknya, ia berkata: seseorang menemui Rasulullah dan berkata: Yaa Rasulullah, sesungguhnya si fulan itu adalah anak saya, saya menzinai ibunya ketika masih masa jahiliyyah. Rasulullah kemudian bersabda bahwa anak itu merupakan anak bagi suami dari perempuan yang melahirkan dan bagi pezina adalah batu (hukumannya). ${ }^{16}$ Berawal dari hadist inilah, para ulama sepakat untuk bahwa status anak diluar nikah memiliki hubungan nasab dengan ibunya maupun keluarga ibunya. Pendapat inilah yang kemudian di tuliskan dalam UU perkawinan tentang status anak diluar pernikahan.

Dalam hukum islam, cara untuk menentukan nasab seseorang dapat dilakukan dengan salah satu dari tiga cara. Pertama, dengan cara kelahiran yaitu didasarkan pada pernikahan yang sah. Kedua, dengan cara inqar atau pengakuan seseorang terhadap seorang anak bahwa anak tersebut adalah anaknya. Ketiga dengan cara bayyinah atau pembuktian yaitu dengan cara membuktikan dengan bukti-bukti yang sah. ${ }^{17}$

Penulis dalam tulisan ini akan membagi makna "anak diluar perkawinan" menjadi dua bagian. Pertama, anak diluar perkawinan yang dilakukan dengan tidak memenuhi syarat yang ditentukan oleh agama dan negara. Kedua, anak diluar perkawinan yang dilakukan dengan tidak memenuhi persyaratan yang ditentukan oleh negara. Hal ini dilakukan untuk mendudukkan dengan benar posisi kasus yang terjadi pada putusan MK ini.

\footnotetext{
${ }^{14}$ http://www.eramuslim.com/ustadz-menjawab/anak-di-luar-nikah-tidak-mendapat-hakwaris.htm \#.UlUovdJHKIw

${ }^{15}$ Abdu Ar-Rahman Al-Mubarakfuri,Tuhfah Al-Ahwadzi, Juz V hal 393.

${ }^{16}$ Muhammad Roy, Dekonstruksi undang-undang hukum islam, Fakultas Ilmu Agama Islam UII, Yogyakarta, 2013. Hlm: 279-280.

${ }^{17}$ Ibid, 279
} 
Hadist yang dikutip diatas tentang ketiadaan nasab yang mengacu kepada lakilaki yang menjadi ayah dari anak merupakan keadaan sebuah hubungan badan yang tidak berpijak pada landasan agama maupun negara, sehingga keadaan zina atau berhubungan badan tanpa pernikahan secara agama tetap menjadi sebuah larangan yang diatur dalam agama maupun negara. Hal ini berbeda dengan kondisi yang dialami pada kasus diatas berkaitan dengan pernikahan yang telah dilaksanakan oleh Machica Mochtar dengan Moerdiono yang syarat secara agama telah terpenuhi, artinya Muhammad iqbal secara sah memiliki nasab terhadap Moerdiono terkait dengan hubungan keperdataannya.

Hal yang menjadi pertanyaan selanjutnya terkait dengan kasus ini ialah bagaimana dengan posisi anak yang kemudian lahir tanpa adanya ikatan sah, baik secara agama maupun negara. Inilah yang kemudian menjadi ijtihad dari Mahkamah Konstitusi terkait dengan adanya putusan tersebut, Mahkamah konstitusi kemudian tetap memberikan hak keperdataan yang dimiliki antara anak dengan laki-laki atau bapaknya dan keluarga laki-laki tersebut. Hal ini dikarenakan agar terjadi perlindungan terhadap sang anak dari hak kostitusionalnya yang dirugikan jika tidak ia dapatkan.

Putusan ini sama sekali tidak mengandung atau setidak-tidaknya mengarah pada legalisasi zina. Putusan ini hanya mengacu pada sebab dari adanya sebuah hubungan yang dilakukan tanpa adanya syarat pernikahan yang terpenuhi, baik secara agama maupun negara, hak-hak anak di luar perkawinan atau anak yang dilahirkan di luar perkawinan yang sah (anak hasil nikah siri, hasil zina/selingkuh) mengalami ketidak-adilan, diskriminasi serta pelanggaran terhadap Hak Asasi Manusia terhadap anak. ${ }^{18}$ sehingga akibat yang muncul tersebut jangan sampai menimbulkan sebuah kerugian lain yang berimplikasi pada pihak yang tidak melakukan kesalahan dalam hal ini adalah anak yang dilahirkan.

Putusan Mahkamah Konstitusi ini pada dasarnya melindungi beberapa hak-hak dasar anak yang dijamin dalam UU No.23 tahun 2002 tentang perlindungan anak pasal 4 sampai pasal 18 yang memberikan perlindungan antara lain.

${ }^{18}$ Siti Musdah Mulia, Islam dan Hak Asasi Manusia: Konsep dan Implementasi (Yogyakarta: Naufan Pustaka, 2010), hlm 254. 
1) Hak untuk dapat hidup, tumbuh, berkembang, dan berpartisipasi secara wajar sesuai dengan harkat dan martabat kemanusiaan serta mendapat perlindungan dari kekerasan dan diskriminasi;

2) Hak untuk beribadah menurut agamanya, berfikir, dan berekspresi sesuai dengan tingkat kecerdasan dan usianya, dalam bimbingan orang tuanya;

3) Hak untuk mengetahui orang tuanya, dibesarkan, dan diasuh oleh orang tuanya sendiri;

4) Hak mendapat perlindungan dari perlakuan:

a) diskriminasi;

b) eksploitasi, baik ekonomi maupun seksual;

c) penelantaran;

d) kekejaman, kekerasan, dan penganiayaan;

e) ketidakadilan; dan

f) perlakuan salah lainnya; dan

5) hak diasuh oleh orang tuanya sendiri. ${ }^{19}$

Selain itu dalam KUHP pasal 277 dan 278 yang menyatakan tentang penggelapan asal-usul anak ${ }^{20}$ dan pengakuan palsu terhadap anak. ${ }^{21} \mathrm{Hal}$ ini berarti bahwa nasb dari anak merupakan hal yang sangat penting dan harus dilindungi terlepas dari hal apapun yang melatar belakanginya.

\section{F. PENUTUP}

Mahkamah Konstitusi sebagai sebuah lembaga yang memiliki peran dalam menguji Undang-Undang terhadap Undang-Undang Dasar dalam hal politik perundang-undangan yang terjadi dalam pembahasan diatas merupakan sebuah lembaga yang mimiliki kewenangan secara sah untuk menyatakan sah atau tidaknya sebuah undang-undang, dan dalam hal ini Mahkamah Konstitusi justru memberikan pembaharuan norma dalam pasal 43 UU perkawinan no 1 tahun 1974, yakni

\footnotetext{
${ }^{19}$ UU RI Nomor 23 tahun 2002 Tentang Perlindungan Anak Pasal 4-18.

${ }^{20}$ KUHP pasal 277 berbunyi "Barangsiapa dengan suatu perbuatan sengaja menggelapkan asalusul seseorang, diancam karena penggelapan asal-usul, dengan pidana penjara paling lama enam tahun".

${ }^{21}$ KUHP pasal 278 berbunyi "Barang siapa mengaku seorang anak sebagai anaknya menurut kitab undang-undang hukum perdata, padahal diketahui bahwa dia bukan bapak dari anak tersebut, diancam, karena melakukan pengakuan palsu, dengan pidana penjara paling lama tiga tahun”.
} 
memberikan hak konstitusional bagi anak yang dilahirkan di luar nikah baik yang pernikahannya tidak sah secara agama maupun secara Negara.

Undang-Undang Perkawinan No. 1 Tahun 1974 merupakan sebuah UndangUndang yang didasarkan pada Hukum Islam. Putusan Mahkamah Konstitusi terkait dengan penambahan pada pasal 43 ayat (1) UU perkawinan ini ternyata masih bernafaskan Islam sebagaimana perjuangan ummat Islam untuk dapat mengaplikasikan nilai-nilai agamanya dalam undang-undang ini. Putusan ini juga sama sekali bebas dari penyimpangan hukum islam sebagaimana ditakutkan kalangan ummat islam terkait dengan legalisasi zina yang terkandung dalam putusan tersebut karena putusan ini berbicara mengenai implikasi dari perbuatan bukan pada asal perbuatan, sehingga perlu kiranya agar tidak terjadi kesimpangsiuran makna yang terkandung dalam putusan ini, penulis berharap masyarakat menerima dengan baik putusan atau hasil ijtihad yang dilakukan Mahkamah Konstitusi dalam membumikan hukum Islam di Indonesia, sehingga nilai-nilai hukum Islam selalu bisa dijadikan dasar dalam mencapai tujuan negara dengan baik.

\section{DAFTAR PUSTAKA}

Abdu Ar-Rahman Al-Mubarakfuri,Tuhfah Al-Ahwadzi, Juz V.

Dadan Muttaqien, Legislasi Hukum Islam di Indonesia Dalam Prespektif Politik Hukum, http://master.islamic.uii.ac.id/index.php/Artikel/Legislasi-Hukum$\underline{\text { Islam-di-Indonesia-dalam-Prespektif-Politik-Hukum.html }}$

Jazim Hamidi, Bahan kuliah magister hukum Universitas Islam Indonesia.

Moh. Mahfud MD, Politik Hukum di Indonesia, Edisi revisi, Rajawali Press, Jakarta, 2009.

Muhammad Roy, Dekonstruksi undang-undang hukum islam, Fakultas Ilmu Agama Islam UII, Yogyakarta, 2013.

Ni'matul Huda, Lembaga Negara dalam masa Transisi Demokrasi, UII Press, Yogyakarta, 2007.

Wawan Hermawan, Pengaruh Konfigurasi Politik terhadap Hukum Perkawinan di Indonesia, $\quad$ http://file.upi.edu/Direktori/FPIPS/M K D U/19740209200501lWAWAN HERMAWAN/Pengaruh Konfig Politik trhdp Huk PerkJurnal FPIPS.pdf 
http://news.detik.com/read/2013/06/04/110906/2264095/10/hakim-agungputusan-mk-soal-anak-biologis-menusuk-perasaan-umat-islam.

http://www.eramuslim.com/ustadz-menjawab/anak-di-luar-nikah-tidak-mendapathak-waris.htm $\not$.UlUovdJHKIw.

http://www.indonesia-investments.com/id/budaya/agama/item69

Undang-Undang Dasar 1945

Kitab Undang-undang Hukum Pidana (KUHP)

Undang-Undang RI Nomor 23 Tahun 2002 Tentang Perlindungan Anak. 